\title{
Kecerdasan Emosional, Stres Akademik, dan Kesejahteraan Subjektif pada Mahasiswa
}

\author{
Sari Julika1 ${ }^{1}$ D Diana Setiyawati ${ }^{2}$ \\ Fakultas Psikologi Universitas Gadjah Mada
}

\begin{abstract}
The objective of this study was to understand the relationship between academic stress, emotional intelligence, and subjective well-being in college student. Hypothesis for this study is academic stress and emotional intelligence can predict someone's subjective wellbeing. This study utilized a quantitative survey method. Participants of this study were 132 college students from different majors who lived in Yogyakarta, men and women, with ages varied from 18 to until 30s. Measurement tools that utilized in the study were academic stress, emotional intelligence scale, and student subjective well-being. Data was analyzed using regression analysis. Academic stress and emotional intelligence were found to predict someone's subjective well being $(\mathrm{F}=9.862 ; \mathrm{p}<0.001)$.
\end{abstract}

Keywords : academic stress; college student; emotional intelligence; subjective well-being

\begin{abstract}
Abstrak. Tujuan dari penelitian ini adalah mengetahui hubungan antara kecerdasan emosional, stres akademik, dan kesejahteraan subjektif pada mahasiswa. Hipotesis yang diajukan adalah stres akademik dan kecerdasan emosi secara bersama-sama dapat memprediksi kesejahteraan subjektif mahasiswa. Penelitian ini menggunakan metode penelitian kuantitatif survei. Partisipan pada penelitian ini adalah 132 mahasiswa perguruan tinggi dari berbagai program studi di Yogyakarta, laki-laki dan perempuan, usia 18-30 tahun. Alat ukur yang digunakan dalam penelitian ini adalah skala stres akademik, skala kecerdasan emosi, dan skala kesejahteraan subjektif mahasiswa. Hasil data dianalisis dengan menggunakan analisis regresi. Hipotesis diterima dengan nilai F 9,862 dan signifikansi $\mathrm{p}<0,001$.
\end{abstract}

Kata kunci : kecerdasan emosi; kesejahteraan subjektif; mahasiswa; stres akademik

Orang-orang selalu menginginkan kehidupan yang lebih baik atau bisa disebut dengan "the good life". Adapun indikator dari kehidupan yang baik adalah ketika individu berpikir dan merasa bahwa kehidupannya layak dan sesuai harapannya terlepas dari penilaian orang lain (Diener, 2009b). Konsep ini kemudian dikenal dengan nama kesejahteraan subjektif atau subjective well-being (SWB).
Kesejahteraan subjektif pertama kali dikenalkan oleh Ed Diener pada tahun 1984 (Diener, 1984; Diener, 2009b). Menurut Diener (2009b), kesejahteraan subjektif (SWB) meliputi tiga aspek, yaitu kepuasan hidup, banyaknya afek positif yang dirasakan individu, dan sedikitnya afek negatif yang dirasakan.

Pada awalnya psikologi berfokus seputar distress dan gangguan, oleh karena

\footnotetext{
1 Korespondensi mengenai isi artikel ini dapat dilakukan melalui sari.julika07@gmail.com

2 atau melalui diana psy@ugm.ac.id
} 
itu psikologi positif berfokus pada pengalaman yang menyenangkan, seperti kesejahteraan, kesenangan, dan kepuasan terhadap hidup (yang telah berlalu), harapan dan optimisme (pada masa depan). Menurut Diener dan Lucas (2000) perbandingan antara penelitian mengenai hal-hal negatif individu dibandingkan dengan hal positif adalah 17:1, yang berarti penelitian mengenai psikologi positif masih sangat kurang. Hal ini menyebabkan pentingnya penelitian mengenai kesejahteraan subjektif pada individu.

Berbicara mengenai kesejahteraan subjektif, maka salah satu pembahasan yang cukup menarik adalah kesejahteraan pada mahasiswa. Pada penelitian awal mengenai kesejahteraan subjektif mahasiswa, mereka diasumsikan memiliki tingkat kesejahteraan yang sama layaknya para orang dewasa, namun penelitian yang telah dilakukan membuktikan bahwa asumsi tersebut tidak benar. Mahasiswa memiliki tingkat kesejahteraan subjektif yang lebih rendah dibandingkan orang dewasa pada umumnya (O'connor, 2005). Suasana pendidikan di sekolah menengah atas dan perguruan tinggi tentunya berbeda, dan seringkali perubahan suasana ini membawa dampak bagi emosi, sosial, dan akademik individu (Lolaty, Ghahari, Tirgari, \& Fard, 2012; Julia \& Veni, 2012), terutama bagi mahasiswa yang baru pertama kali memiliki pengalaman tinggal jauh dari rumah (Prabu, 2015; Mesidor \& Sly, 2016).

Menjadi seorang mahasiswa membawa suatu status baru bagi individu, di mana mahasiswa diharapkan menjadi agent of change. Status ini menjadi suatu beban dan tanggung jawab yang harus diemban individu, terlepas dari tugas dan kewajibannya menjadi seorang mahasiswa sesuai dengan peraturan yang berlaku ditempatnya menimba ilmu. Hal ini diungkapkan oleh Direktorat Jenderal
Pendidikan Tinggi (Center for Public Mental Health [CPMH], 2012) bahwa lulusan perguruan tinggi diharapkan menjadi pribadi yang memiliki kualitas penguasaan ilmu pengetahuan dan teknologi yang tinggi, didukung dengan kemampuan softskill yang memadai.

Tugas dan tanggung jawab ini memengaruhi kondisi kesejahteraan subjektif mahasiswa. Penelitian Nugraheni (2012) menunjukkan bahwa 31,8\% mahasiswa tahun pertama memiliki tingkat kesejahteraan subjektif yang sedang, dan 22,7\% memiliki kesejahteraan subjektif yang rendah. Berdasarkan analisis Utami pada tahun 2011 (dalam $\mathrm{CPMH}$, 2012) menunjukkan bahwa sebagian besar mahasiswa yang melakukan konsultasi psikologi di Gadjah Mada Medical Center (GMC) memiliki masalah terkait perasaan tidak bersemangat, tertekan, gangguan tidur, gangguan konsentrasi, bingung, putus asa, dorongan untuk mengakhiri hidup, dan bahkan ada beberapa yang telah melakukan percobaan bunuh diri. Fenomena bunuh diri di kalangan mahasiswa menjadi permasalah serius dalam beberapa tahun terakhir, contohnya saja pada tahun 2017, K (23 tahun) mahasiswa ITN Malang bunuh diri di rumah kosong (Hartik, 2017), tahun 2016, E (20 tahun), bunuh diri di rumahnya di daerah Jakarta (Nailufar, 2016), tahun 2015, ada seorang mahasiswa Yogyakarta (L, 19 tahun) yang memilih bunuh diri di kamar kosnya, mahasiswa IPB (M, 21 tahun) gantung diri di kamar kosnya, pada tahun 2014, J (23 tahun) memilih bunuh diri dikamar kos, dan masih banyak lagi kasus bunuh diri mahasiswa yang tidak terekspos media (Dewantara, 2015).

Kesejahteraan mahasiswa menjadi isu penting di berbagai negara, sehingga banyak layanan mengenai kesejahteraan subjektif pada mahasiswa. Di Indonesia sendiri, salah satu yang berfokus pada 
kesejahteraan subjektif mahasiswa adalah Center for Public Mental Health (CPMH) UGM. CPMH, sebagai salah satu unit kerja Psikologi UGM pernah mengadakan workshop mengenai program kampus Indonesia sejahtera (CPMH, 2012). Latar belakang workshop ini adalah banyaknya permasalahan yang dihadapi mahasiswa, seperti yang dikutip berikut:

"Masalah-masalah akademis terutama disebabkan oleh ketidakmampuan untuk menyesuaikan diri dengan tuntutan studi, misalnya akibat salah memilih jurusan, metode pembelajaran yang berbeda dengan SMA, cara dosen mengajar, tugas perkuliahan, masalahmasalah dalam pengerjaan skripsi, dan kehawatiran terhadap karier dan masa depan. Permasalahan non-akademis teru-tama berasal dari tekanan sosial yang dialami mahasiswa sehari-hari seperti permasalahan yang terkait engan keluarga, misalnya karena tinggal terpisah dari keluarga, kondisi keuangan keluarga, riwayat pola pengasuhan asuh dari orangtua, perbedaan prinsip dengan orang tua. Selain itu masalah-masalah yang bersumber dari kehidupan di pondokan, hubungan perteman dengan latar belakang sosial dan budaya yang berbeda, kesulitan adaptasi umum, masalah dalam hubungan lawan jenis, serta masalah di dalam organisasi dan kegiatan kemahasiswaan sering merupakan sumber permasalahan yang serius bagi mahasiswa" (CPMH, 2012)

Segala bentuk permasalahan yang dihadapi mahasiswa tersebut dinamakan gangguan psikologis, mulai dari yang ringan seperti stres, hingga terberat seperti depresi dan percobaan bunuh diri. Stres psikologis adalah respon subjektif individu terhadap lingkungannya yang dirasa membebani atau melebih kapasitas adaptifnya. Stres dapat bermanfaat jika memberikan motivasi pada individu untuk berubah, tetapi stres yang berlebihan dapat merusak individu baik secara fisik maupun psikologis (Saddki, Sukerman \& Mohamad, 2017). Secara umum, stres akademik dapat dikatakan stres yang bersumber pada kegiatan akademik. Termasuk di dalamnya penugasan yang terlalu banyak, kompetisi dengan teman sekelas, kegagalan proses belajar, ujian, penilaian, prestasi akademik, dan kurangnya waktu luang (Rakhmawati, Farida, dan Nurhalimah, 2014), belajar, mengerjakan PR, tes, praktikum, membaca literatur, kuis, dan mengatur waktu antara kuliah dan kegiatan ekstra kurikuler (Prabu, 2015).

Temuan dalam penelitian Risdiantoro, Iswinarti, dan Hasanati (2016) menunjukkan bahwa mahasiswa PTS memiliki tingkat stres akademik lebih tinggi daripada mahasiswa PTN terkait persaingan dalam memasuki dunia kerja. Hal yang sama ditemukan dalam penelitian Wahed dan Hassan (2017) bahwa persaingan dengan mahasiswa dari kampus lain menjadi salah satu faktor yang memperburuk kondisi depresi mahasiswa. Yumba (2008) mengatakan bahwa stres akademk adalah hal yang paling memengaruhi kondisi stres mahasiswa dibandingkan lingkungan, hubungan interpersonal, dan masalah pribadi.

Kesejahteraan subjektif adalah salah
satu indikator kesehatan mental mahasiswa (Kitzrow, 2003), dan kecerdasan emosional dapat memprediksi kesehatan mental seseorang (Jayalakshmi \& Magdalin, 2015). Penelitian terdahulu menunjukkan hubungan yang kuat antara kesejahteraan subjektif dan stres (Serrano \& Andreu, 2016), kepuasan hidup dan stres di sekolah (Moksnes, dkk, 2016), serta hubungan antara kesejahteraan subjektif dan kecerdasan emosional (Baburao \& Deshmukh, 2014; Cazan \& Nastasa, 2014;). 
Penelitian mengenai kegiatan akademik pada mahasiswa juga menunjukkan bahwa stres akademik dan kecerdasan emosional (Fallahzadeh, 2011) berkorelasi dengan prestasi akademik (Khan \& Kausar, 2013; Aspiras \& Aspiras, 2014; Banerjee \& Chatterjee, 2016,) dan akhirnya memengaruhi kesejahteraan subjektif.

Kecerdasan emosional pertama kali diperkenalkan oleh Mayer, Salovey, dan Caruso pada tahun 1997 (dalam Salovey \& Grewal, 2005; Rivers, Brackett, Salovey \& Mayer, 2007) dan direvisi pada tahun 2010 (dalam Mayer, Salovey, Caruso, \& Cherkasskiy, 2011) menjadi kemampuan untuk menafsirkan dan mengekspresikan emosi, mengasimilasikan emosi pada pikiran, memahami dan memberikan alasan dengan emosi, dan meregulasi emosi pada diri dan orang lain. Kecerdasan emosional menurut Mayer dan rekan ini adalah berbasis kemampuan (ability based) (Fernandez-Berrocal \& Extremera, 2016)

Penelitian ini bertujuan untuk mengetahui apakah stres akademik dan kecerdasan emosional secara bersamasama mampu memprediksi kesejahteraan subjektif mahasiswa. Sejauh ini studi literatur yang peneliti temukan hanya berbicara mengenai hubungan antara kesejahteraan subjektif dan stres akademik maupun kesejahteraan subjektif dan kecerdasan emosional secara terpisah, tetapi jarang yang menggunakan ketiga variabel tersebut secara bersama-sama. Oleh karena itu peneliti ingin melihat hubungan ketiga variabel ini secara bersama-sama, dengan menggunakan kesejahteraan subjektif sebagai variabel dependen dan stres akademik serta kecerdasan emosional sebagai variabel prediktor.

Hipotesis yang diajukan pada penelitian ini adalah stres akademik dan kecerdasan emosi secara bersama-sama dapat memprediksi kesejahteraan subjektif mahasiswa.

\section{Metode}

Subjek yang berpartisipasi pada penelitian ini sebanyak 132 orang yang terdiri dari 26 laki-laki dan 106 perempuan. Usia berkisar antara 18 - 30 tahun, dengan rata-rata usia 23,14 tahun. Pemilihan partisipan menggunakan metode random sampling (sampel acak) dan snowball (pesan berantai).

Penelitian ini melibatkan tiga variabel, yaitu variabel kecerdasan emosional, stres akademik, dan kesejahteraan. Instrumen penelitian yang digunakan adalah skala yang disebarkan secara online melalui jejaring sosial WhatsApp, Facebook, Twitter, dan Google+.

\section{Kesejahteraan subjektif}

Variabel kesejahteraan subjektif diukur menggunakan Skala Kesejahteraan Subjektif Mahasiswa milik Utami (2010) terbagi menjadi tiga subskala, yaitu subskala kepuasan hidup, subskala afek positif, dan subskala afek negatif. Jumlah aitem untuk subskala afek positif adalah 27 aitem, afek negatif 29 aitem, dan kepuasan hidup 26 aitem. Pilihan jawaban menggunakan skala Likert bergerak dari 1 (sangat tidak puas), 2 (tidak puas), 3 (biasa saja), 4 (puas), 5 (sangat puas). Nilai koefisien reabilitas subskala afek positif adalah 0,920, subskala afek negatif sebesar 0,937 dan subskala kepuasan hidup mahasiswa sebesar 0,872 .

Stres akademik

Variabel stres akademik diukur menggunakan Skala Stres Akademik milik Nugraheni (2012) yang mengukur aktivitas akademik terkait proses belajar dan evaluasi belajar dan terdiri dari 30 aitem favorabel. Pilihan jawaban menggunakan skala Likert $1-5$. Koefisien reabilitas skala sebesar 0,922 . 
Tabel 1.

Hasil Analisis Korelasi

\begin{tabular}{llllc}
\hline \multicolumn{4}{c}{ Model Summary } \\
\hline Model & $\mathrm{R}$ & R Square & Adjusted R Square & $\begin{array}{c}\text { Std. Error of the } \\
\text { Estimate }\end{array}$ \\
\hline 1 & $.368^{\text {a }}$ & .135 & .122 & 2.15732 \\
\hline a. Predictors: (Constant), TPPE, Stress \\
\hline
\end{tabular}

Kecerdasan emosional

Variabel kecerdasan emosi diukur menggunakan TPPE (Tes Pemahaman dan Pengelolaan Emosi). TPPE adalah alat ukur yang telah dimodifikasi menjadi versi ringkas dari STEU-B (Allen, Weissman, MacCann, Helwig, E Robert, 2014) dan STEM-B (Allen, Rahman, Weissman, MacCan, Lewis, E Roberts, 2015). TPPE terdiri dari 12 aitem, yaitu tujuh aitem yang mengacu pada STEU-B dan lima aitem yang mengacu pada STEM-B. Tujuh aitem berupa pernyataan yang mengandung muatan emosi tertentu, dimana partisipan diminta untuk memilih kata yang menunjukkan emosi yang tepat, dan lima aitem berupa kasus yang mengandung muatan emosi, dimana partisipan diminta untuk memilih respon emosi yang paling tepat. Koefisien reliabilitas alat ukur sebesar 0,720.

Data dianalisis dengan menggunakan analisis regresi berganda menggunakan bantuan program SPSS 16 for Windows.

\section{Hasil}

Uji hipotesis dilakukan dengan menggunakan regresi ganda. Hasil menunjukkan signifikansi $0,000(p<0,001)$ yang menunjukkan bahwa hasil signifikan dan variabel stres akademik dan kecerdasan emosional dapat digunakan untuk memprediksi kesejahteraan subjektif. Hasil koefisien korelasi antara variabel kesejahteraan subjektif, stres akademik, dan kecerdasan emosional menunjukkan hasil $\mathrm{R}=0,368$, dan koefisien determinannya $\left(\mathrm{R}^{2}\right)=0,135$ (Lihat tabel 1$)$. Artinya variabel stres akademik dan kecerdasan emosional secara bersamasama menyumbang sebesar 13,5\% terhadap kesejahteraan subjektif mahasiswa dan 86,5\% lainnya disumbangkan melalui faktor lain. Persamaan garis regresinya adalah:

$$
\mathrm{Y}=2.324-0.037 \text { stress }+0.094 \mathrm{TPPE}
$$

Tabel 2.

Hasil Analisis Regresi Berganda

\begin{tabular}{|c|c|c|c|c|c|c|}
\hline \multicolumn{7}{|c|}{ ANOVA $^{b}$} \\
\hline Model & & $\begin{array}{l}\text { Sum of } \\
\text { Squares }\end{array}$ & $\mathrm{df}$ & Mean Square & $\mathrm{F}$ & Sig. \\
\hline \multirow[t]{3}{*}{1} & Regression & 91.800 & 2 & 45.900 & 9.862 & $.000^{\mathrm{a}}$ \\
\hline & Residual & 586.410 & 126 & 4.654 & & \\
\hline & Total & 678.210 & 128 & & & \\
\hline \multicolumn{7}{|c|}{ a. Predictors: (Constant), TPPE, Stress } \\
\hline \multicolumn{7}{|c|}{ b. Dependent Variable: SWB } \\
\hline
\end{tabular}


Hasil uji hipotesis dengan menggunakan analisis regresi ganda menunjukkan nilai $\mathrm{F}=9,862$ dengan signifikansi $0,000(\mathrm{p}<0,001)$ (Lihat tabel 2). Dengan demikian hipotesis yang mengatakan bahwa stres akademik dan kecerdasan emosional secara bersamasama dapat memprediksi kesejahteraan subjektif mahasiswa diterima. Koefisien korelasinya sebesar 0,368 dan koefisien determinannya 0,135. Artinya variabel stres akademik dan kecerdasan emosional mampu memprediksi kesejahteraan subjektif sebesar $13,5 \%$ dan sisanya $86,5 \%$ ditentukan oleh faktor lain.

\section{Diskusi}

Berdasarkan analisis tambahan diketahui bahwa stres akademik menjadi prediktor yang lebih kuat dibandingkan kecerdasan emosional. Penelitian yang dilakukan Denovan dan Macaskill (2017) pada 192 mahasiswa tahun pertama di UK, yaitu dengan pengukuran pada saat tiga minggu pertama kuliah, dan enam bulan setelahnya. Hasil penelitian menunjukkan level stres pada mahasiswa tetap stabil meskipun waktu berlalu, dan terdapat peningkatan alienasi terhadap kegiatan akademik dan self-efikasi menurun. Stres yang terus-menerus berasosiasi negatif terhadap kepuasan hidup dan berasosiasi positif terhadap afek negatif pada kedua pengukuran ( 3 minggu dan 6 bulan), tetapi pada afek positif hanya berasosiasi negatif pada pengukuran kedua (6 bulan).

Adapun variabel kecerdasan emosional tidak menunjukkan pengaruh yang signifikan terhadap kesejahteraan subjektif dalam penelitian ini. Meskipun begitu, beberapa penelitian mengenai kesejahteraan subjektif menunjukkan hasil sebaliknya, yaitu kecerdasan emosional berbasis kemampuan mampu memprediksi kesejahteraan subjektif (Sánchez-Álvarez, Extremera, dan Fernández-Berrocal, 2016). Skala kecerdasan emosional milik Wardhani (2016) mengacu pada model kecerdasan emosional berbasis kemampuan milik Mayer, Salovey dan Caruso, meskipun begitu menurut Sánchez-Álvarez et al. (2016) hubungan antara kecerdasan emosional dan kesejahteraan subjektif menunjukkan korelasi yang lebih kuat jika menggunakan skala pengukuran kecerdasan emosional yang mixed model dibandingkan dengan hanya menggunakan laporan diri (self-report).

Reviu literatur yang dilakukan Fernandez-Berrocal dan Extremera (2016) mengenai hubungan antara kecerdasan emosional dan kesejahteraan subjektif mengajukan beberapa pertanyaan penelitian. Pertama, berdasarkan penelitian Gohm dan rekan (dalam Fernandez-Berrocal dan Extremera, 2016) bahwa individu dengan kecerdasan emosional tinggi akan mengalami lebih sedikit distress secara emosi ketika dihadapkan pada situasi yang menyebabkan stres, yang akan mengakibatkan peningkatan afek positif dan kesejahteraan secara umum dibandingkan dengan individu yang memiliki kecerdasan emosional rendah. Kedua, kemungkinan besar, seseorang dengan kecerdasan emosional tinggi lebih mampu mengelola self-esteem dan efikasi diri ketika berhadapan dengan situasi yang menyebabkan stres, sehingga emosi negatif tidak memengaruhi kesejahteraannya (Salguero et al., dalam Fernandez-Berrocal dan Extremera, 2016). Ketiga, seseorang dengan kecerdasan emosi tinggi mampu menjalin hubungan baik dengan orang lain, sehingga memperkuat dukungan sosial bagi dirinya, dan akhirnya dukungan sosial akan mampu meningkatkan kesejahteraannya (Lopez et al., dalam Fernandez-Berrocal dan Extremera, 2016). Keempat, menurut Matthewa dan rekan (dalam FernandezBerrocal dan Extremera, 2016), seseorang 
dengan kecerdasan emosional yang tinggi mampu melakukan strategi koping yang positif, misalnya dengan mengekspresikan emosi, dan mencari bantuan, dibandingkan menghindar atau lari dari masalah. Berdasarkan temuan ini, Fernandez-Berrocal dan Extremera (2016) mengasumsikan bahwa kecerdasan emosional berpotensi sebagai variabel mediasi pada hubungan antara kesejahteraan subjektif dengan variabel lain, semisal kepribadian, stres, dan strategi koping positif. Faktor-faktor lain yang memengaruhi kesejahteraan subjektif adalah faktor kepribadian dan hubungan sosial.

\section{Faktor kepribadian}

Menurut Lucas dan Diener (2009) kesejahteraan subjektif cenderung stabil dari waktu ke waktu, meskipun kehidupan terus berubah. Teori big five dari McCrae dan Costa (dalam Diener, 2009a) menunjukkan kepribadian ekstraversi berkorelasi dengan afek positif dan kepribadian neurotis berkorelasi dengan afek negatif. Penelitian Gray (dalam

Argyle, 2001) menunjukkan bahwa terdapat perbedaan struktur otak di mana seorang ekstravert bereaksi dengan hadiah dan penghargaan, sehingga menjadi lebih bahagia, sedangkan seorang neurotik bereaksi terhadap hukuman, sehingga menjadi tidak bahagia. Larsen and Ketelaar (dalam Argyle, 2001) menemukan bahwa seorang ekstravert lebih dipengaruhi oleh mood positif dibandingkan seorang introvert. Termasuk di dalam kepribadian adalah self-esteem, self-efficacy, optimism, dan lain-lain (Diener, 2009a).

Hubungan sosial (pertemanan, relationship, keterlibatan dalam komunitas)

Penelitian yang dilakukan oleh Morgan, Vera, Gonzales, Conner, Vacek, \& Coyle, (2011) pada 159 remaja awal dengan etnis berbeda untuk melihat kesejahteraan subjektif berdasarkan individual, hubungan dengan keluarga, teman, sekolah, dan tetangga menunjukkan hasil bahwa keluarga menjadi prediktor pada afek negatif, sementara individual, sekolah dan teman menjadi prediktor pada afek positif, dan individual dan keluarga memprediksi kepuasan hidup.

Penelitian Nugraheni

menunjukkan bahwa aktivitas yang berhubungan dengan materi pembelajaran, pengelolaan waktu antara aktivitas akademik dan non akademik dan pencapaian akademik menjadi stressor utama pada mahasiswa tahun pertama. Sementara pada mahasiswa akhir, aktivitas akademik yang menjadi stressor adalah aktivitas akademik yang berhubungan dengan ujian dan penyelesaian tugas. Untuk aktivitas akademik yang berhubungan dengan teman sebaya dan dosen tidak terdapat perbedaan antara keduanya.

Penelitian Utami (2009) mengenai kesejahteraan mahasiswa di Yogyakarta menemukan bahwa keterlibatan dalam berbagai kegiatan (akademik, nonakademik, kegiatan profit dan non-profit, dan kegiatan mengisi waktu luang) dapat meningkatkan kesejahteraan mahasiswa. Mahasiswa yang terlibat aktif didalam berbagai aktivitas memiliki kesejahteraan yang lebih tinggi dibandingkan mereka yang tidak memiliki aktivitas.

\section{Kesimpulan}

Stres akademik dan kecerdasan emosional secara bersama-sama berkontribusi terhadap kesejahteraan subjektif mahasiswa. Meskipun begitu, peran stres akademik ditemukan lebih besar terhadap kesejahteraan subjektif mahasiswa dibandingkan dengan kecerdasan emosional. 
Saran

Peneliti selanjutnya dapat mengambil jumlah sampel yang lebih besar atau melakukan spesifikasi sampel penelitian (usia, jenis kelamin, tingkat pendidikan, prestasi akademik, tingkat perkembangan, suku). Spesifikasi terhadap salah satu dari empat faktor kecerdasan emosi (pengelolaan emosi, pemahaman emosi, penggunaan emosi yang tepat, identifikasi emosi), terutama pada aspek penggunaan emosi yang tepat dan identifikasi emosi dapat dikaji di penelitian selanjutnya.

\section{Kepustakaan}

Allen, V. D., Weissman, A., MacCann, C., Helwig, S., \& Robert, R. D. (2014). Development of the situational test of emotional understanding-brief (STEU-B) using item response theory. Personality and Individual Differences, 65, 3-7. doi: 10.1016/j.paid.2014.01.051

Allen, V., Rahman, N., Weissman, A., MacCan, C., Lewis, C., \& Roberts, R. D. (2015). The situational test of emotional management-brief (STEM-B): Development and validation using item response theory and latent class analysis. Personality and Individual Differences, 81, 195-200. doi: 10.1016/j.paid.2015.01.053

Aspiras, L. S., \& Aspiras, E. D. (2014). Perceived stress factors and academic performance of the sophomore IT students of QSU Cabarroguis campus. International Conference on Economics, Education and Humanities, Indonesia, 137-142. doi: 10.15242/ICEHM.ED1214125

Argyle, M. (2001). The psychology of happiness (Edisi kedua). New York, NY: Taylor and Francis Inc.

Baburao, P. V., \& Deshmukh, N. V. (2014). Assertiveness, emotional intelligence and subjective well-being of college students. Golden Research Thoughts, $3(8)$.

Banerjee, N., \& Chatterjee, I. (2016). Academic stress, suicidal ideation \& mental well-being among 1st semester \& 3rd semester medical, engineering \& general stream students. Journal of Arts, Science $\mathcal{E}$ Commerce, 7(3), 73-80. doi: 10.18843/rwjasc/v7i3/09

Cazan, A., \& Năstasă, L.E. (2014). Emotional intelligence, satisfaction with life and burnout among university students. Procedia - Social and Behavioral Sciences 180, 1574 1578 .

doi: 10.1016/j.sbspro.2015.02.309

Center for Public Mental Health. (2012). Program kampus Indonesia sejahtera, Dasar pemikiran. Diunduh dari http://cpmh.psikologi.ugm.ac.id/kes ehatan-mental-sekolah/programkampus-indonesia-sejahtera/dasarpemikiran/

Denovan, A., \& Macaskill, A. (2017). Stress and subjective well-being among first year UK undergraduate students. Journal of Happiness Studies, 18(2), 505-525. doi: 10.1007/s10902016-9736-y.

Dewantara, J. R. (2015). Fenomena bunuh diri di kalangan mahasiswa. Diunduh dari https://hiburanjogjablog.wordpress.c om/2015/12/22/fenomena-bunuhdiri-di-kalangan-mahasiswa/

Diener, E. (1984). Subjective well-being. Psychological Bulletin, 95(3), 542-575. Diunduh dari https://internal.psychology.illinois.e du/ ediener/Documents/Diener 198 4.pdf (diakses pada 5 Maret 2017)

Diener, E. (2009a). Assessing subjective well-being: Progress and opportunities. In E. Diener (Ed.), Assessing Well-being: Social Indicator 
Research Series, 39, 25-65. Netherlands: Springer.

Diener, E. (2009b). Subjective well-being. In E. Diener (Ed.), The Science of WellBeing: Social Indicator Research Series, 37, 11-58. Netherlands: Springer.

Diener, E., \& Lucas, R. E. (2000). Subjective emotional well-being. In M. H.-J. Lewis, Handbook of Emotions Second Edition (pp. 471-484). New York: The Guilford Press.

Fallahzadeh, H. (2011). The relationship between emotional intelligence and academic achievement in medical science students in Iran. Procedia Sosial and Behavioral Sciences, 30, 14611466.

doi: 10.1016/j.sbspro.2011.10.283.

Fernandez-Berrocal, P., \& Extremera, N. (2016). Ablity emotional intelligence, depression, and well-being. Emotion Review, 8(4), 311-315. doi: 10.1177/1754073916650494.

Hartik, A. (2017). Sebelum bunuh diri mahasiswa ITN sempat ikut bimbingan skripsi. Diunduh dari http://regional.kompas.com/read/20 17/03/02/21335741/sebelum.bunuh.di ri.mahasiswa.itn.sempat.ikut.bimbin gan.skripsi

Jayalakshmi, V., \& Magdalin, S. (2015). Emotional intelligence, resilience and mental health of women college students. Journal of Psychosocial Research, 10(2), 401-408.

Julia, M., \& Veni, B. (2012). An analysis of the factors affecting students' adjustment at a university in Zimbabwe. International Education Studies, 5(6), 244-250. doi: 10.5539/ies.v5n6p244.

Kitzrow, M. A. (2003). The mental health needs of today's college students: Challenges and recommendations. NASPA Journal, 41(1), 167-181. doi: 10.2202/1949-6605.1310.
Khan, M.J., Altaf, S., \& Kausar, H. (2013). Effect of perceived academic stress on students' performance. FWU Journal of Social Sciences, 7(2), 146-151.

Lolaty, Ghahari, Tirgari, \& Fard, (2012). The effect of life skills training on emotional intelligence of the medical sciences students in iran. Indian Journal of Psychological Medicine, 34(4), 350-354. doi: 10.4103/02537176.108217

Lucas, R. E., \& Diener, E. (2009). Personality and subjective wellbeing. In E. Diener (Ed.), The science of well-being: Social indicator research series (Vol. 37, pp. 75-102). Netherlands: Springer.

Mayer, J. D., Salovey, P., Caruso, D. R., \& Cherkasskiy, L. (2011). Emotional intelligence. In R. J. Stenberg (Ed.), The Cambridge Handbook of Intelligence (pp. 528-649). New York, NY: Cambridge University Press.

Mesidor, J. K., \& Sly, F. K. (2016). Factors that contribute to the adjustment of international students. Journal of International Students, 6(1), 262-282

Moksnes, U. K., Løhre, A., Lillefjell, M., Byrne, D. G., \& Haugan, G. (2016). The association between school stress, life satisfaction and depressive symptoms in adolescents: Life satisfaction as a potential mediator. Social Indicator Research, 125, 339-357. doi: 10.1007/s11205-014-0842-0.

Morgan, M. L., Vera, E. M., Gonzales, R. R., Conner, W., Vacek, K. B., Coyle, L. D. (2011). Subjective well-being in urban adolescents: Interpersonal, individual, and community influences. Youth $\mathcal{E}$ Society, 43(2), 609-634.

doi: 10.1177/0044118X09353517

Nailufar, N. N. (2016). Mahasiswa bunuh diri, diduga karena skripsi ditolak dan putus cinta. Diunduh dari http://megapolitan.kompas.com/rea 
d/2016/07/27/18015261/mahasiswa.b unuh.diri.diduga.karena.skripsi.dito lak.dan.putus.cinta

Nugraheni, A. K. (2012). Stres akademik dan kesejahteraan subjektif pada mahasiswa tingkat pertama dan tingkat akhir. Skripsi tidak diterbitkan. Yogyakarta: Fakultas Psikologi UGM O'connor, E. (2005). Student well-being: A dimension of subjective well-being? http://www.acqol.com.au/publicatio ns/resources/thesis-oconnor-e.pdf (diakses pada 31 Juli 2017)

Prabu, S. (2015). A study on academic stress among higher secondary students. International Journal of Humanities and Social Science Invention, 4(10), 63-68.

Rakhmawati, I., Farida, P., \& Nurhalimah. (2014). Sumber stress akademik dan pengaruhnya terhadap tingkat stress mahasiswa keperawatan DKI Jakarta. Jurnal Keperawatan, 2(3), 7284.

Risdiantoro, R., Iswinarti, \& Hasanati, N. (2016). Hubungan prokrastinasi akademik, stres akademik dan kepuasan hidup mahasiswa. Seminar Asean 2nd psychology dan humanity, pp. 360-373.

Rivers, S. E., Brackett, M. A., Salovey, P., \& Mayer, J. D. (2007). Measuring emotional intelligence as a set of mental abilities. In G. Matthew, M. Zeidner, \& R. D. Roberts (Eds). The Science of emotional intelligence: knowns and unknowns (pp. 230-257). New York, NY: Oxford University Press.

Saddki, N., Sukerman, N., \& Mohamad, D. (2017). Association between Emotional intelligence and perceived stress in undergraduate dental students. The Malaysian Journal of Medical Sciences, 24(1), 59-68. doi:

10.21315/mjms2017.24.1.7.
Salovey, P., \& Grewal, D. (2005). The science of emotional intelligence. Current Directions in Psychological Science, 14(6), 281-285. doi: 10.1111/j.0963-7214.2005.00381.x.

Sánchez-Álvarez, N., Extremera, N., \& Fernández-Berrocal, P. (2016). The relation between emotional intelligence and subjective wellbeing: A meta-analytic investigation. The Journal of Positive Psychology, 11(3), 276-285. doi: 10.1080/17439760.2015.1058968.

Serrano, C. \& Andreu, Y. (2016). Perceived emotional intelligence, subjective well-being, perceived stress, engagement and academic achievement of adolescents. Revista de Psicodidáctica, 21(2), 357-374. doi: 10.1387/revpsicodidact.14887.

Utami, M. S. (2009). Keterlibatan dalam kegiatan dan kesejahteraan subjektif mahasiswa. Jurnal Psikologi, 36(2), 144-163. doi: 10.22146/jpsi.7892.

Utami, M. S. (2010). Skala kesejahteraan subjektif mahasiswa. Laporan penelitian (tidak diterbitkan). Yogyakarta: Fakultas Psikologi UGM.

Wahed, W., \& Hassan, S. (2017). Prevalence and associated factors of stress, anxiety and depression among medical Fayoum University students. Alexandria Journal of Medicine, 53, 77-84. doi: 10.1016/j.ajme.2016.01.005.

Wardhani, R. K. (2016). Pengaruh program "Remaja Bijak" terhadap kecenderungan perilaku agresif remaja (Tesis tidak dipublikasikan). Yogyakarta: Universitas Gadjah Mada.

Yumba, Z. (2008). Academic stress: A case of undergraduate students (paper). Institutionen för beteendevetenskap och lärande : Linkoping University. 